\title{
INFLUENCE OF SOIL AMENDMENTS AND \\ TILLAGE METHODS AGAINST SUNFLOWER CHARCOAL ROT DISEASE UNDER RECLAIMED SOIL
}

\author{
Abeer E. Elhadidy \\ Department of Plant Protection, Desert Research Center, El-Matareya, \\ Cairo, Egypt \\ E-mail: elhadidyabeer@gmail.com
}

$\mathrm{F}$

ield experiments were carried out at El-Nubaria Province, the desert backyard of El-Behaira Governorate, Egypt, during two successive summer seasons (2016 and 2017), to study the effect of the integration between different tillage methods and soil amendment treatments on damping-off and charcoal rot diseases management of sunflower caused by Macrophomina phaseolina under the reclaimed soil conditions. Conventional tillage (CT) was found to be more effective in reducing M. phaseolina population and charcoal rot. Rice straw + $\mathrm{EM} 1+$ Urea $\times \mathrm{EM}-\mathrm{X}$ or biochar + compost $\times \mathrm{EM}-\mathrm{X}$ were found to be more effective in reducing damping-off and charcoal rot disease incidence and severity as well as $M$. phaseolina population. Therefore, enhanced sunflower productivity compared to the other examined soil amendment treatments; including the conventional chemical fertilization as the control treatment. The integration between $\mathrm{CT}$ method and rice straw $+\mathrm{EM} 1+$ Urea $\times \mathrm{EM}-\mathrm{X}$ or biochar + compost $\times$ EM-X was found to be more effective in reducing M. phaseolina population and charcoal rot incidence and severity. The integration between tillage methods and soil amendments was found to be the furthermost advised agricultural practices under these conditions as land degradation neutrality (LDN) technology that enhances land cover and area unit productivity under these conditions.

Keywords: Macrophomina phaseolina, Helianthus annuus, tillage, soil amendments, LDN

Sunflower (Helianthus annuus L.) is an important member of the family Asteraceae and one of the major oilseed crops grown for edible oil in the world (Anonymous, 2007). In Egypt, serious shortages in edible oil supplies are dominant due to the limited cultivation areas and the rapid increase of demands resulting from the steady population growth. This gap 
between supplies and demands in edible oils could be overcome through either by horizontal expansion (introduction the oil crops into the crop pattern of the newly reclaimed lands) or by vertical expansion (implementation of more efficient agricultural practices) as reported by Dawood et al. (2012).

Sunflower diseases are one of the major constraints in influencing production stability of this crop worldwide. Charcoal rot caused by Macrophomina phaseolina (Tassi) Goid is a major plant disease, which is assumed to case economically damaging proportions for more than 500 plant species in the arid and semiarid areas of the world (Purkayastha et al., 2006). M. phaseolina is the most important pathogen of sunflower in warmer countries (Sadashivaiah et al., 1986). Chemical pesticides pose serious health hazards to the applicator, as well as killing various beneficial organisms as a result of the environmental pollution (Bouizgarne, 2013).

Agricultural practices can deal efficiently with many environmental problems, and thus, mitigate enormous challenges that face contemporary agriculture including plant diseases. It ensures the implementation of the Millennium Sustainable Development Goals (Singh et al., 2011). Various agricultural practices are known to directly or indirectly affect a biotic stress, populations of soil borne pathogens and the severity of their resultant root diseases. The integration of some practices, such as tillage, organic fertilization, crop rotation, and residue management, can also increase microbial activity in the rhizosphere and thus enhances the crop growth and productivity (Raaijmakers et al., 2009). Tillage is a mechanical soil manipulation for seedbed preparation, that affects the rate and trend of soil degradation. In addition to establishing the seed-soil contact, tillage is used to alleviate soil compaction and so improve infiltration capacity; to dispose of pathogen-infested crop residue; to incorporate fertilizer into the root zone, and to eradicate weeds. The kind of tillage and its frequency depend on the soil and its related constraints to crop production. Wide range tillage alleviates unfavorable soil conditions (FAO, 1995). It also increases drainage and soil temperature that lead to reduce the severity and damage of root rot pathogens to many crops (Dang et al., 2015 and Verrell et al., 2017). The use of organic amendments is one of the successful control methods of soil-borne diseases. Similarly, biochar, which is a carbon rich soil amendment that is produced as a by-product during the pyrolysis of the agriculture wastes to produce the thermal gas, can significantly improve the gravimetric moisture content of soil (Kumar et al., 2018).

Using effective microorganisms (EM) improves crop growth and yield by increasing photosynthesis, producing bioactive substances; such as hormones and enzymes, controlling soil diseases, accelerating decomposition of lignin materials in the soil and generally improves soil physical and chemical properties and favors the growth and efficiency of 
symbiotic microorganisms; such as nitrogen fixing rhizobia and arbuscular mycorrhizal (AM) fungi (Figueiredo et al., 2016).

The present study was undertaken with an objective to assess the ability of different tillage methods and different soil amendments on sunflower charcoal rot management under the Egyptian reclaimed soil conditions.

\section{MATERIALS AND METHODS}

An experiment was carried out in a field naturally infested with $M$. phaseolina (experienced previous history of charcoal rot disease incidence) at El-Nubaria Province, the desert backyard of El-Behaira Governorate, Egypt during the two successive growing seasons of 2016 and 2017, to investigate the effect of the integration between different tillage methods and soil amendment treatments on charcoal rot management under reclaimed soil conditions. Isolation of pathogenic fungi and pathogenicity test had been done in a previous study (Abdel-Ati and El-Hadidy, 2015).

The physical and chemical properties of the experimental soil were determined and included the following characters: sand $91.40 \%$, silt $3.50 \%$, clay $5.10 \%, \mathrm{pH} 7.68$, organic matter $0.18 \% . \mathrm{CaCO}_{3} 1.00 \%$, E.C. 0.50 mmhos $/ \mathrm{cm}^{3}$. The available total $\mathrm{N}, \mathrm{P}, \mathrm{K}$ were $7.50,2.80,18.0 \mathrm{ppm}$, respectively at 0-60 cm depth as described by Chapman and Pratt (1978).

Three Tillage methods designated by Triplett et al. (1986) were used in the present study. These tillage methods were (1) No-tillage $(\mathrm{NT})=$ no plowing before seed bed preparation, (2) Moderate tillage $(\mathrm{MT})=$ retaining a minimum of $30 \%$ surface cover with residues, (3) Conventional tillage $(\mathrm{CT})=$ clean till, i.e. most or all the previous crop residues was buried.

The treatment advice adding only $50 \%$ or $100 \%$ of the complete doses of the conventional chemical fertilization during the soil preparation i.e. $150 \mathrm{~kg}$ calcium super phosphate/fed $\left(15.5 \% \mathrm{P}_{2} \mathrm{O}_{5}\right)$, and $45 \mathrm{~kg} \mathrm{~N} / \mathrm{fed}$ as ammonium sulphate $(20.6 \% \mathrm{~N})$ in three equal doses at sowing, after thinning and pre-configured buds flowering, in addition to $50 \mathrm{~kg} /$ fed potassium sulphate $\left(48 \% \mathrm{~K}_{2} \mathrm{O}\right)$ was added after plant thinning. The rest of the experiment received only the soil amendment treatments (organic amendments were added into each plot in the rate of $20 \mathrm{~m}^{3} / \mathrm{fed}$ and mixed with the soil before planting $\times$ biofertilizers were added with irrigation water and foliar application) which were as follows:

- Conventional: full dose of the recommended dose of the chemical fertilization.

- RS + EM1 + Urea $\times$ EM-X: rice straw (after fermentation with EM1 and water for two months) (in order to adjust the $\mathrm{C} / \mathrm{N}$ ratio) $\times \mathrm{EM}-\mathrm{X}(\mathrm{EM} 1+$ Bacillus subtilus + Azotobacter Chrococcum + Arbuscular Mycorrhiza) [4 L/ fed with irrigation water $(0.4 \%)+2 \mathrm{~L} /$ fed foliar application $(7.5 \%)$ ] 
- RS + EM1 + Urea $\times$ EM5: rice straw (after fermentation with EM1 and water for two months) (in order to adjust the $\mathrm{C} / \mathrm{N}$ ratio) $\times$ EM5 $[4 \mathrm{~L} /$ fed with irrigation water $(0.4 \%)+2 \mathrm{~L} /$ fed $(7.5 \%)$ foliar application]

- Biochar + compost $\times$ EM-X: biochar of rice straw $(2 \% \mathrm{w} / \mathrm{w})$ and compost (in order to adjust the $\mathrm{C} / \mathrm{N}$ ratio) $\times \mathrm{EM}-\mathrm{X}[4 \mathrm{~L} /$ fed with irrigation water $(0.4 \%)+2 \mathrm{~L} / \mathrm{fed}(7.5 \%)$ foliar application]

- Biochar + compost $\times$ EM5: biochar of rice straw $(2 \% \mathrm{w} / \mathrm{w})$ and compost (in order to adjust the $\mathrm{C} / \mathrm{N}$ ratio) $\times$ EM5 [4 L/fed with irrigation water $(0.4 \%)+2 \mathrm{~L} / \mathrm{fed}(7.5 \%)$ foliar application]

The experimental design that was used in this experiment was split plot design in four replicates, where the tillage methods occupied the main plots, the soil amendment treatments were arranged in the sup ones. The organic amendments were added into each plot in the rate of $20 \mathrm{~m}^{3} / \mathrm{fed}$ and mixed with the soil before planting, while biofertilizers were added with irrigation water and foliar application. The effective microorganisms EM5 is a modification product from EM1 (selected species of microorganisms including predominant populations of lactic acid bacteria and yeasts, and smaller numbers of photosynthetic bacteria, actinomycetes and other types of organisms; such as mycorrhizae) that created by adding vinegar and ethyl alcohol during the fermentation process in order to have multifunction product such as foliar fertilizer and insect repellent (Higa, 2000). Later on, the new modification of EM-X was made by Abdel-Ati and El-Hadidy (2017) as a new formula for EM1 through different experiments for series of Bacillus subtilis + Azotobacter Chrococcum + arbuscular mycorrhiza, which were fermented in the classical EM1 for 45 days before usage. The EM1 was kindly obtained from EM project-EEAA-Ministry state of Environmental Affairs, while the liquid culture of Bacillus subtilis, Azotobacter chrococcum and arbuscular mycorrhiza were kindly obtained from microbial research center (Cairo-MIRCEN), the unite biofertilizers, Faculty of Agriculture, Ain Shames University.

Seeds of sunflower var. Giza- 102 were obtained from Agricultural Research Center, Giza, Egypt, and were sown at 15 March in both seasons at seeding rates $5 \mathrm{~kg} / \mathrm{fed}$ (3-5 seeds per hill) and thinned at 15 days after sowing date.

\section{Disease Assessment}

At seedling stage: Damping-off was assessed as percentage of the preand post-emergence damping-off 15 and 45 days after planting.

At maturity stage: Charcoal-rot was assessed as disease incidence and disease severity before harvest. Disease incidence was evaluated as percentage of the disease plants 90 days after planting according to Morsy (2005).

The disease severity index of this study was calculated by the modification of Cralley's system of disease measurement according to 
Bhattacharya et al. (1985). The extent of M. phaseolina infection was indicated due to the presence of dark brown lesion and micro-sclerotia of the fungus on root-systems. The healthy and infected plants were divided into four groups as following:

- Healthy plants $(0=$ No charcoal root-rot symptom $)$

- Slightly infected ( $1=$ Slight charcoal root-rot symptom plants)

- Heavily infected ( $2=$ Heavy charcoal root-rot symptom plants)

- Dead plants (3= Dead seedlings).

Disease Severity Index (D.S.I) was calculated as follows:

Where:-

$$
\text { D.S.I. }=\frac{0\left(\mathrm{H}^{\mathrm{n}}\right)+1\left(\mathrm{~S}^{\mathrm{n}}\right)+2\left(\mathrm{H}^{\mathrm{m}}\right)+3\left(\mathrm{D}^{\mathrm{n}}\right)}{\text { Total number of plants examined }}
$$

$\left(\mathrm{H}^{\mathrm{n}}\right)=$ Number of healthy plants

$\left(\mathrm{S}^{\mathrm{n}}\right)=$ Number of slightly infected plants

$\left(\mathrm{H}^{\mathrm{m}}\right)=$ Number of heavily infected plants

$\left(D^{\mathrm{n}}\right)=$ Number of dead plants

\section{Determination of Microbial and Macrophomina sp. Populations}

Soil samples were obtained from each treatment to a depth of $15 \mathrm{~cm}$. The population of microsclerotia of Macrophomina sp. was evaluated by the assaying of a single $10 \mathrm{~g}$ subsample from each sample, using the technique and semi selective medium previously described by Mihail and Alcorn (1982). Microbial populations were evaluated by using suspension of $1 \mathrm{~g}$ (dry weight equivalent) in $10 \mathrm{ml}$ of sterile water. One $\mathrm{ml}$ of the soil suspension was then diluted serially (ten-fold) and used to estimate bacterial and fungal total counts by standard spread-plate dilution method as described by Seeley and Van Damark (1981).

\section{Harvest}

A random sample of ten plants were taken from each plot at harvest time of both seasons to determine the following; plant height $(\mathrm{cm})$, head diameter $(\mathrm{cm})$, seed yield $(\mathrm{kg} / \mathrm{fed})$ and the oil yield $(\mathrm{kg} / \mathrm{fed})$, which was estimated by grounding dry mature seeds into very fine powder to determine oil percentage using Soxhlet apparatus and diethyl ether according to A.O.A.C. (1990), then the oil yield was estimated by multiplying seed oil percentage by seed yield $(\mathrm{kg} / \mathrm{fed})$.

\section{Statistical Analysis}

Pooled data were subjected to the combined statistical analysis after passing the homogeneity test using M-STAT C (Russell, 1991), while Duncan's multiple range test was used to verify the significant differences between treatments means as described by Duncan (1955). 


\section{RESULTS}

\section{Effect of Tillage Methods}

\subsection{On damping-off and charcoal rot diseases}

Data in figs. (1 and 2) underline that, the proper tillage method is one of the agricultural practices that reduce both damping-off and charcoal rot diseases in sunflower. Conventional tillage (CT) was the most effective tillage method to reduce both pre and post emergence damping-off compared to moderately tillage (MT) and no tillage (NT) methods (Fig. 1). Consequently, data in fig. (2) illustrate that, both $\mathrm{CT}$ and MT reduced significantly incidence and severity of charcoal rot disease compared to NT. It also could be concluded that the disease incidence and severity were less in CT than other tillage methods (Fig. 2).

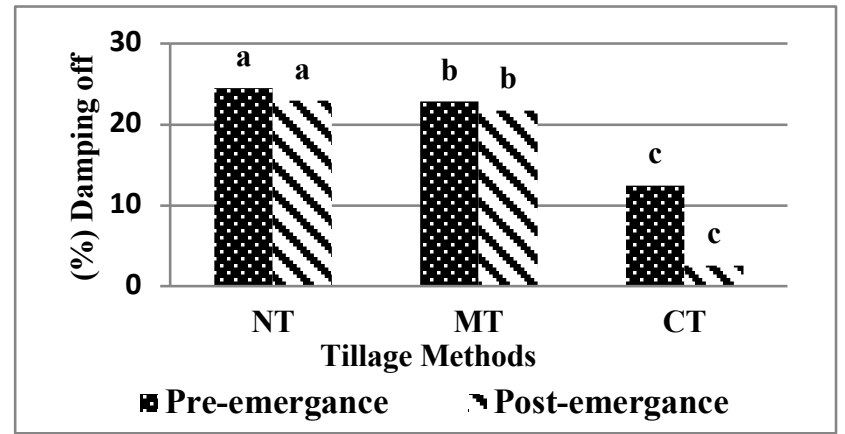

Fig. (1). Effect of tillage methods on damping-off disease.

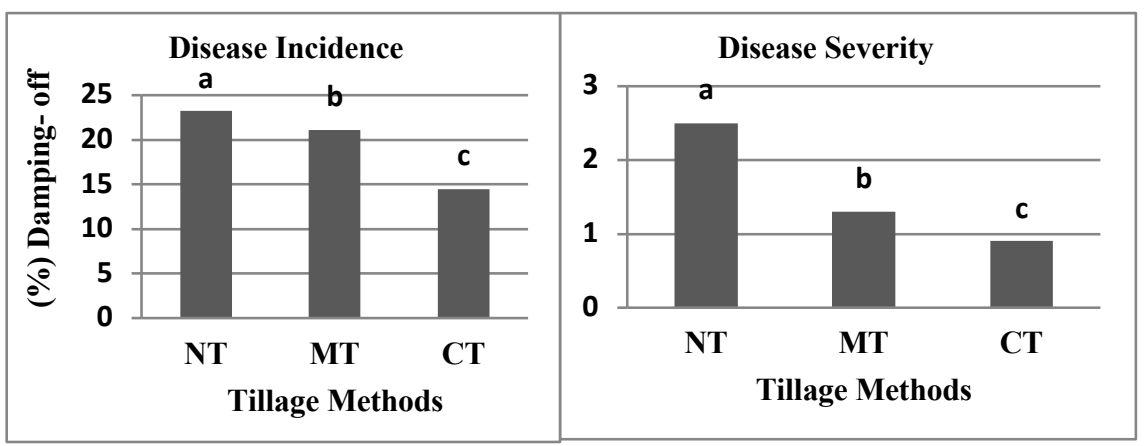

Fig. (2). Effect of tillage methods on charcoal rot disease. D.S. was calculated according to Bhattacharya et al. (1985).

$\mathrm{NT}=$ no-tillage, $\mathrm{MT}=$ moderately tillage, $\mathrm{CT}=$ Conventional tillage Means having similar letters at same column have no significant differences at $P \geq$ 0.05

Egyptian J. Desert Res., 68, No. 2, 223-242 (2018) 


\subsection{On microbial and Macrophomina sp. populations}

Data in fig. (3) emphasis that, the proper tillage method as one of the agricultural practices did not suppress $M$. phaseolina population density. It was clear that, there were no significant dereference between the three examined tillage methods; i.e. no tillage, moderate tillage and conventional tillage on Macrophomina sp. populations density. However, results show that, tillage methods as an agriculture practice played an important role in encouraging the soil microbial populations. The bacterial and fungal total counts showed high significant increase with conventional tillage compared to moderately and no tillage, respectively (Fig. 3).

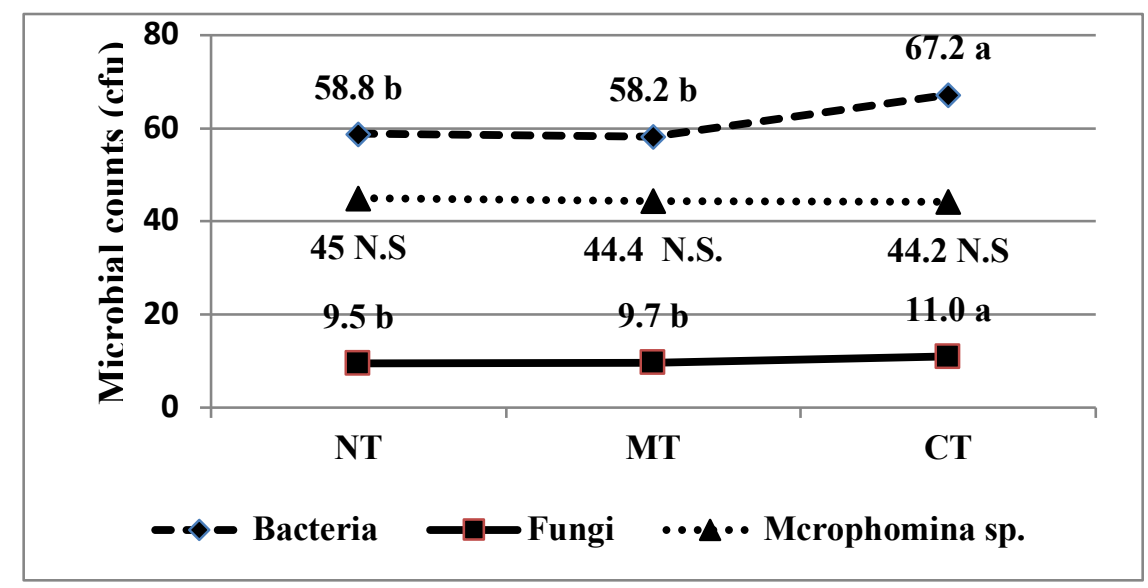

Fig. (3). Effect of tillage methods on microbial counts and Macrophomina sp. populations.

$\mathrm{NT}=$ no-tillage, $\mathrm{MT}=$ moderate tillage, $\mathrm{CT}=$ Conventional tillage Means having similar letters at same column have no significant differences at $P \geq 0.05$

\subsection{On sunflower yield and growth characters}

Data in table (1) highlight the effect of different tillage methods on sunflower yield and growth characters under the dominancy of sunflower damping-off and charcoal rot diseases. The observations emphasis that under these conditions of abiotic stresses using conventional tillage method as one of the agricultural practices was more appreciated in increasing significantly all the studied characters of sunflower yield and growth characters; i.e. plant height $(\mathrm{cm})$, stem diameter $(\mathrm{cm})$, head diameter $(\mathrm{cm})$, seed yield $(\mathrm{kg} / \mathrm{fed})$ and the oil yield $(\mathrm{kg} / \mathrm{fed})$ compared to moderately tillage and no tillage, respectively. 
Table (1). Effect of different tillage methods on sunflower yield growth characters grown under Nubaria province conditions.

\begin{tabular}{lcccc}
\hline & \multicolumn{4}{c}{ Studied characters } \\
\cline { 2 - 5 } Tillage Method & $\begin{array}{c}\text { Plant } \\
\text { height } \\
\text { (cm) }\end{array}$ & $\begin{array}{c}\text { Head } \\
\text { diameter } \\
\text { (cm) }\end{array}$ & $\begin{array}{c}\text { Seed } \\
\text { yield } \\
(\mathbf{k g} / \mathbf{f e d})\end{array}$ & $\begin{array}{c}\text { Oil } \\
\text { yield } \\
(\mathbf{k g} / \mathbf{f e d})\end{array}$ \\
\hline No tillage & $143.2 \mathrm{c}$ & $11.1 \mathrm{c}$ & $271.0 \mathrm{c}$ & $77.7 \mathrm{c}$ \\
Moderately tillage & $143.8 \mathrm{~b}$ & $14.1 \mathrm{~b}$ & $368.5 \mathrm{~b}$ & $115.8 \mathrm{~b}$ \\
Conventional tillage & $157.0 \mathrm{a}$ & $16.4 \mathrm{a}$ & $469.1 \mathrm{a}$ & $174.1 \mathrm{a}$ \\
\hline
\end{tabular}

Means having similar letters at same column have no significant differences at $P \geq 0.05$

\section{Effect of Soil Amendment Treatments}

\subsection{On damping-off and charcoal rot diseases}

Data in figs. (4 and 5) indicate that, there was significant impact of soil amendment treatments; i.e. RS + EM1 + Urea $\times \mathrm{EM}-\mathrm{X}, \mathrm{RS}+\mathrm{EM} 1+$ Urea $\times$ EM5), biochar + compost $\times$ EM-X and biochar + compost $\times$ EM5 for suppression of both damping-off and charcoal rot diseases, compared to the conventional chemical fertilization as the control treatment. Data in fig. (4) illustrate that RS + EM1 + Urea $\times$ EM-X treatment had the most significant effective to suppress both pre and post emergence damping-off followed by biochar + compost $\times$ EM-X, RS + EM1 + Urea $\times$ EM5 and biochar + compost $\times$ EM5, respectively, compared to conventional chemical fertilization as the control treatment. Meanwhile, data in fig. (5) show that, there are significant variations between the soil amendment treatments for reducing charcoal rot compared with conventional as a control treatment. RS + EM1 + Urea $\times$ EM-X and biochar + compost $\times$ EM-X treatments showed the minimum disease incidence and severity followed by RS + EM1 + Urea $\times$ EM5 and Biochar + compost $\times$ EM5 (with no significant differences), respectively, compared to conventional as a control treatment (Fig .5).

\subsection{On microbial and Macrophomina sp. populations}

Data in fig. (6) present that, the effective variations of soil amendment treatments i.e. (RS+EM1+Urea $\times$ EM-X), $(\mathrm{RS}+\mathrm{EM} 1+$ Urea $\times$ EM5), (Biochar + compost $\times$ EM-X) and $($ Biochar + compost $\times$ EM5) on Macrophomina sp. populations and soil microbial total counts compared with conventional as a control treatment. Data showed that, the lowest significant populations of Macrophomina sp. was recorded by $(\mathrm{RS}+\mathrm{EM} 1+\mathrm{Urea} \times \mathrm{EM}-\mathrm{X})$ and $(\mathrm{RS}+\mathrm{EM} 1+$ Urea $\times$ EM5) followed by $($ Biochar + compost $\times$ EM-X) and (Biochar + compost $\times$ EM5) treatments respectively, compared with conventional as a control treatment. Meanwhile, the soil amendment treatments encouraged significantly the soil microbial total counts compared to the conventional as a control treatment. The most significant increase in total counts of both soil bacteria and fungi was 
showed by $(\mathrm{RS}+\mathrm{EM} 1+$ Urea $\times$ EM-X) and $(\mathrm{RS}+\mathrm{EM} 1+$ Urea $\times$ EM5), followed by $($ Biochar + compost $\times$ EM-X) and (Biochar + compost $\times$ EM5) respectively, when compared with conventional as a control treatment (Fig. $6)$.

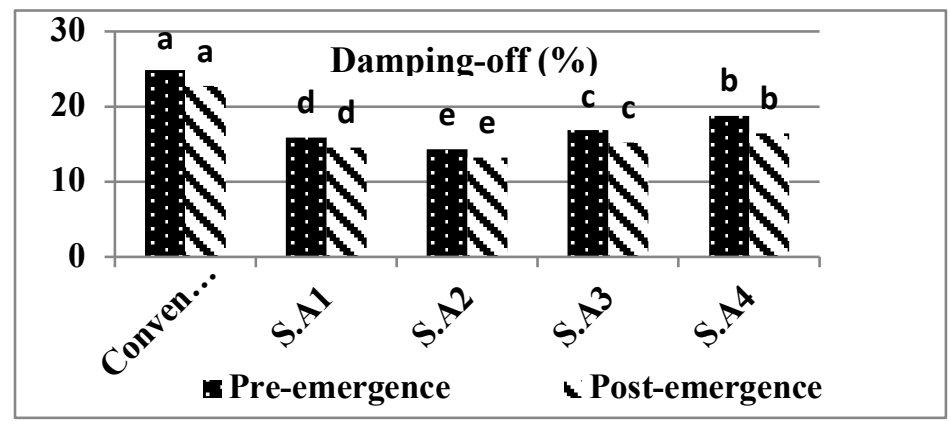

Fig. (4). Effect of soil amendments on damping-off.

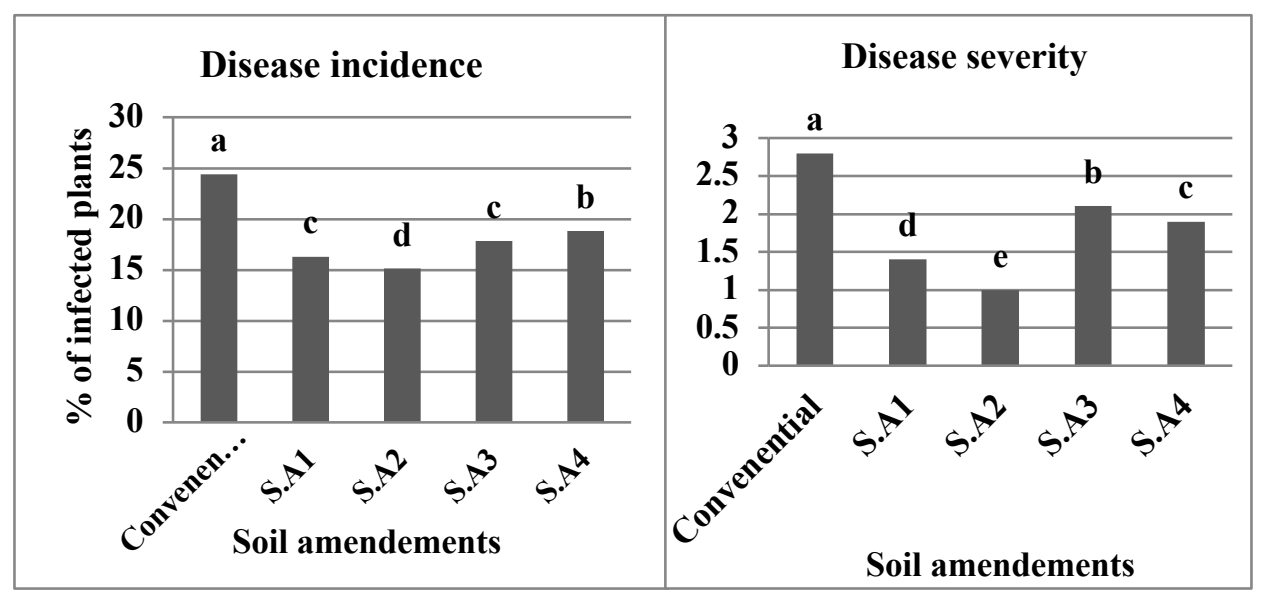

Fig. (5). Effect of soil amendments on charcoal rot. D.S. was calculated according to Bhattacharya et al. (1985).

$\mathrm{S} . \mathrm{A} 1=\mathrm{RS}+\mathrm{EM} 1+$ Urea $\times \mathrm{EM}-\mathrm{X}, \mathrm{S} . \mathrm{A} 2=\mathrm{RS}+\mathrm{EM} 1+\mathrm{Urea} \times \mathrm{EM}$, S.A3= biochar + compost $\times$ EM-X, S.A4= biochar + compost $\times$ EM5

Means having similar letters at same column have no significant differences at $P \geq 0.05$ 


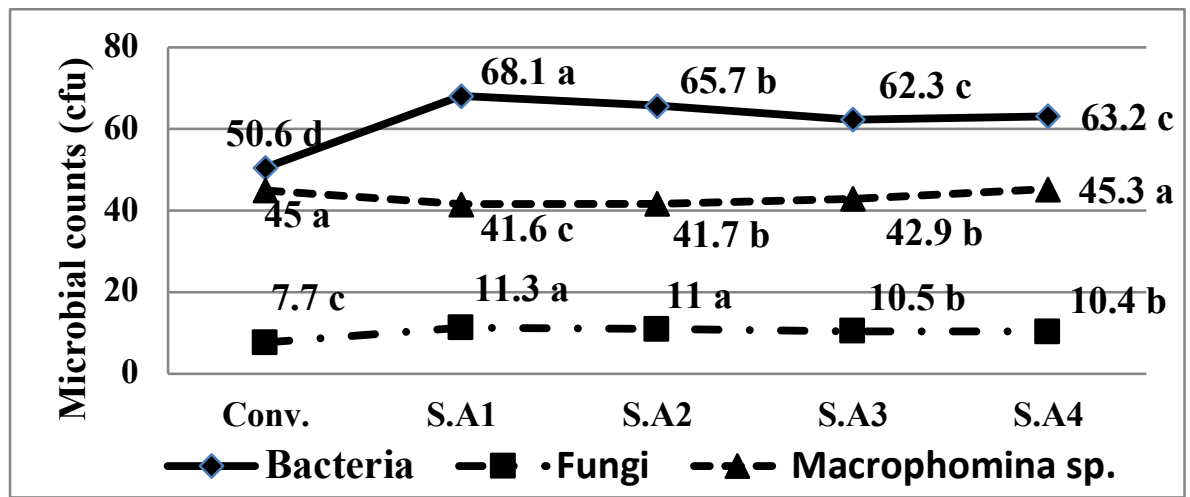

Fig. (6). Effect of soil amendment treatments on soil microbial counts and Macrophomina sp. populations.

$\mathrm{S} . \mathrm{A} 1=\mathrm{RS}+\mathrm{EM} 1+$ Urea $\times \mathrm{EM}-\mathrm{X}, \mathrm{S} . \mathrm{A} 2=\mathrm{RS}+\mathrm{EM} 1+$ Urea $\times \mathrm{EM}$, S.A3= biochar + compost $\times$ EM-X, S.A4 $=$ biochar + compost $\times$ EM5

Means having similar letters at same column have no significant differences at $P \geq 0.05$

\subsection{On sunflower yield and growth characters}

Data in table (2) indicated the effect of different soil amendment treatments on sunflower var. Giza 102 yield and growth characters; i.e. plant height $(\mathrm{cm})$, head diameter $(\mathrm{cm})$, seed yield $(\mathrm{kg} / \mathrm{fed})$ and the oil yield $(\mathrm{kg} / \mathrm{fed})$. Observations illustrated that under the dominancy of the biotic stress of soil borne diseases, the application of the soil amendments was more appreciated to increase sunflower yield and its attributes compared to the conventional chemical fertilization. The highest observations were obtained from RS + EM1 + Urea $\times$ EM-X followed by RS + EM1 + Urea $\times$ EM5, biochar + compost $\times$ EM5, and biochar + compost $\times$ EM5 then the conventional chemical fertilization as control treatment, respectively compared to the conventional chemical fertilization as the control treatment.

\section{Effect of the interaction between tillage methods and soil amendment treatments}

\subsection{On damping-off and charcoal rot diseases}

Data in table (3) indicate that, all the different interactions between tillage methods and soil amendment treatments, reduced significantly damping-off and charcoal rot diseases in sunflower compared to the control treatment (no tillage $\times$ conventional fertilization). At seedling stage; data showed that the interaction treatments $[\mathrm{CT} \times(\mathrm{RS}+\mathrm{EM} 1+$ Urea $\times \mathrm{EM}-\mathrm{X})]$ had the superior significant suppression of pre and post emergence dampingoff, while the minimum suppression were obtained from NT $\times$ conventional fertilizers as the control treatment. At maturity stage; observations revealed that, the superior significant suppression of charcoal rot incidence was 
obtained from the interaction $\mathrm{CT} \times($ Biochar + compost $\times \mathrm{EM}-\mathrm{X})$ followed by $\mathrm{CT} \times($ Biochar + compost $\times \mathrm{EM}-\mathrm{X})$.

Table (2). Effect of different soil amendment treatments on sunflower yield and growth characters grown under Nubaria province conditions.

\begin{tabular}{lcccc}
\hline \multirow{2}{*}{$\begin{array}{l}\text { Soil } \\
\text { amendments }\end{array}$} & \multicolumn{4}{c}{ Studied characters } \\
\cline { 2 - 5 } & $\begin{array}{c}\text { Plant height } \\
(\mathbf{c m})\end{array}$ & $\begin{array}{c}\text { Head diameter } \\
(\mathbf{c m})\end{array}$ & $\begin{array}{c}\text { Seed yield } \\
(\mathbf{k g} / \mathbf{f e d})\end{array}$ & $\begin{array}{c}\text { Oil yield } \\
(\mathbf{k g} / \mathbf{f e d})\end{array}$ \\
\hline Conv. & $139.3 \mathrm{~d}$ & $12.4 \mathrm{c}$ & $322.2 \mathrm{e}$ & $128.6 \mathrm{c}$ \\
S.A1 & $152.4 \mathrm{a}$ & $16.2 \mathrm{a}$ & $423.4 \mathrm{a}$ & $144.0 \mathrm{a}$ \\
S.A2 & $149.8 \mathrm{~b}$ & $15.1 \mathrm{a}$ & $406.8 \mathrm{~b}$ & $135.0 \mathrm{~b}$ \\
S.A3 & $147.2 \mathrm{bc}$ & $13.9 \mathrm{~b}$ & $390.7 \mathrm{c}$ & $126.9 \mathrm{c}$ \\
S.A4 & $145.3 \mathrm{c}$ & $13.8 \mathrm{~b}$ & $376.3 \mathrm{~d}$ & $120.7 \mathrm{~d}$ \\
\hline
\end{tabular}

Conv.$=$ Conventional, S.A1 $=$ RS + EM1 + Urea $\times$ EM-X, S.A2 $=$ RS + EM1 + Urea

$\times$ EM5, S.A3 $=$ biochar + compost $\times$ EM-X, S.A4= biochar + compost $\times$ EM5

Means having similar letters at same column have no significant differences at $P \geq$ 0.05

Table (3). Effect of the interaction between tillage methods and soil amendment treatments on damping-off and charcoal rot.

\begin{tabular}{|c|c|c|c|c|c|}
\hline \multirow{2}{*}{$\begin{array}{l}\text { Tillage } \\
\text { methods }\end{array}$} & \multirow{2}{*}{$\begin{array}{c}\text { Soil } \\
\text { amendments }\end{array}$} & \multicolumn{2}{|c|}{ At seedling stage } & \multicolumn{2}{|c|}{ At mature stage } \\
\hline & & $\begin{array}{c}\text { *Pre- } \\
\text { emergence } \\
\text { damping-off }(\%)\end{array}$ & $\begin{array}{c}* * \text { Post- } \\
\text { emergence } \\
\text { damping-off }(\%)\end{array}$ & $\begin{array}{c}\text { Disease } \\
\text { incidence } \\
(\%)\end{array}$ & $\begin{array}{l}\text { Disease } \\
\text { severity }\end{array}$ \\
\hline \multirow{5}{*}{ No tillage } & Conv. & $28.4 \mathrm{a}$ & $26.3 a$ & $27.6 \mathrm{a}$ & $2.8 \mathrm{a}$ \\
\hline & S.A1 & $20.7 \mathrm{e}$ & $18.6 \mathrm{c}$ & $20.3 \mathrm{de}$ & $1.4 \mathrm{~d}$ \\
\hline & S.A2 & $21.6 \mathrm{~d}$ & $19.5 b c$ & $21.2 \mathrm{~d}$ & $1.6 \mathrm{~d}$ \\
\hline & S.A3 & $21.7 \mathrm{~d}$ & $19.6 \mathrm{bc}$ & $21.3 \mathrm{~d}$ & $2.0 \mathrm{c}$ \\
\hline & S.A4 & $23.6 \mathrm{c}$ & $20.0 \mathrm{~b}$ & $23.1 \mathrm{c}$ & $1.8 \mathrm{~cd}$ \\
\hline \multirow{5}{*}{$\begin{array}{l}\text { Moderately } \\
\text { tillage }\end{array}$} & Conv. & $26.5 b$ & $25.4 a b$ & $25.6 \mathrm{~b}$ & $2.5 \mathrm{~b}$ \\
\hline & S.A1 & $16.5 \mathrm{~g}$ & $17.5 \mathrm{~cd}$ & $15.4 \mathrm{e}$ & $0.5 \mathrm{fg}$ \\
\hline & S.A2 & $18.7 \mathrm{f}$ & $18.8 \mathrm{c}$ & $16.8 \mathrm{e}$ & $0.7 \mathrm{f}$ \\
\hline & S.A3 & $20.7 \mathrm{e}$ & $18.6 \mathrm{c}$ & $20.3 \mathrm{de}$ & $1.4 \mathrm{~d}$ \\
\hline & S.A4 & $22.3 \mathrm{c}$ & $20.4 \mathrm{~b}$ & $20.5 \mathrm{de}$ & $1.0 \mathrm{e}$ \\
\hline \multirow{5}{*}{$\begin{array}{l}\text { Conventional } \\
\text { tillage }\end{array}$} & Conv. & 19.7ef & $16.5 \mathrm{~d}$ & 20.0de & $1.4 \mathrm{~d}$ \\
\hline & S.A1 & $5.7 \mathrm{j}$ & $3.5 \mathrm{~g}$ & $9.5 \mathrm{~g}$ & $0.2 \mathrm{~h}$ \\
\hline & S.A2 & $7.3 \mathrm{i}$ & $5.4 \mathrm{f}$ & $10.4 \mathrm{~g}$ & $0.2 \mathrm{~h}$ \\
\hline & S.A3 & $8.5 \mathrm{i}$ & $5.5 \mathrm{f}$ & $10.5 \mathrm{~g}$ & $0.2 \mathrm{~h}$ \\
\hline & S.A4 & $10.6 \mathrm{~h}$ & $8.7 \mathrm{e}$ & $12.7 \mathrm{f}$ & $0.4 \mathrm{~g}$ \\
\hline & $\begin{array}{l}\text { nventional, } \\
\text { A3= biocha } \\
\text { ing similar }\end{array}$ & $\begin{array}{l}1=\mathrm{RS}+\mathrm{EM} 1+\mathrm{U} \\
\text { ompost } \times \mathrm{EM}-\mathrm{X}, \mathrm{S} \\
\text { ers at same colum } \\
\text { fferences at } P \geq 0.0 \\
\text { culated as percent }\end{array}$ & $\begin{array}{l}\mathrm{a} \times \mathrm{EM}-\mathrm{X}, \mathrm{S} . \mathrm{A} 2= \\
\mathrm{A} 4=\text { biochar }+ \text { com } \\
\text { and similar small } 1 \\
* \text { calculated as per }\end{array}$ & $\begin{array}{l}+\mathrm{EM} 1+\mathrm{U} \\
\mathrm{t} \times \mathrm{EM} 5 \\
\text { ers at the san } \\
\text { tt of number }\end{array}$ & \\
\hline
\end{tabular}




\subsection{On microbial and Macrophomina sp. populations}

Data in table (4) illustrate that the integration between different tillage methods and soil amendment treatments, had significant effects on the microbial total counts of both bacteria and fungi in addition to the total counts of $M$. phaseolina populations in sunflower rhizospere (colonies $\mathrm{x}$ 103/g soil). Regarding the bacterial total count the superior observation was obtained from the integration between $\mathrm{CT} \times($ biochar + compost $\times \mathrm{EM}-\mathrm{X})$ and MT $\times($ biochar + compost $\times$ EM-X) with no significant differences, while the minimum observation was obtained from NT $\times$ conventional fertilization. Regarding the fungi total count, the heist observations were obtained (with no significant differences in between) from CT $\times(\mathrm{RS}+\mathrm{EM} 1$ + Urea $\times$ EM-X), CT $\times$ biochar + compost $\times$ EM-X) and CT $\times(\mathrm{RS}+\mathrm{EM} 1$ + Urea $\times$ EM5), respectively, while the minimum total fungal count was obtained from NT $\times$ conventional fertilization. In addition, In respect to $M$. phaseolina populations in sunflower rhizosphere, the highest reduction was obtained from MT $\times(\mathrm{RS}+\mathrm{EM} 1+\mathrm{Urea} \times \mathrm{EM}-\mathrm{X})$ and CT $\times(\mathrm{RS}+\mathrm{EM} 1+$ Urea $\times$ EM-X), respectively, but with no significant differences. While the lowest reduction was obtained from NT $\times$ conventional fertilization, MT $\times$ conventional fertilization and then $\mathrm{CT} \times$ conventional fertilization, respectively with no significant differences as well.

Table (4). Effect of the interaction between different sawing methods and soil biofertilizer treatments on microbial total counts and Macrophomina phaseolina populations in sunflower rhizosphere (colonies $\times 10^{3} / \mathrm{g}$ soil).

\begin{tabular}{|c|c|c|c|c|c|c|c|c|c|}
\hline \multirow{3}{*}{$\begin{array}{l}\text { Soil } \\
\text { amendments }\end{array}$} & \multicolumn{3}{|c|}{ No tillage } & \multicolumn{3}{|c|}{ Moderately tillage } & \multicolumn{3}{|c|}{ Conventional tillage } \\
\hline & \multicolumn{2}{|c|}{$\begin{array}{l}\text { Microbial } \\
\text { counts }\end{array}$} & \multirow{2}{*}{$\begin{array}{l}\text { Macro- } \\
\text { phomina } \\
\text { sp. }\end{array}$} & \multicolumn{2}{|c|}{$\begin{array}{l}\text { Microbial } \\
\text { counts }\end{array}$} & \multirow{2}{*}{$\begin{array}{l}\text { Macro- } \\
\text { phomina } \\
\text { sp. }\end{array}$} & \multicolumn{2}{|c|}{$\begin{array}{l}\text { Microbial } \\
\text { counts }\end{array}$} & \multirow{2}{*}{$\begin{array}{l}\text { Macro- } \\
\text { phomina } \\
\text { sp. }\end{array}$} \\
\hline & B & $\mathbf{F}$ & & B & $\mathbf{F}$ & & $\mathbf{B}$ & $\mathbf{F}$ & \\
\hline Conv. & $48.6 \mathrm{~Eb}$ & $7.4 \mathrm{Cb}$ & $47.5 \mathrm{Aa}$ & $47.5 \mathrm{Db}$ & $7.0 \mathrm{Cb}$ & 46.9Aa & $55.9 \mathrm{Dc}$ & $8.8 \mathrm{Ca}$ & $46.6 \mathrm{Aa}$ \\
\hline S.A1 & $64.5 \mathrm{Bc}$ & $10.4 \mathrm{Ab}$ & 42.3Da & $65.9 \mathrm{Ab}$ & $10.0 \mathrm{Bb}$ & 41.6Da & $67.4 \mathrm{Ba}$ & $12.5 \mathrm{Aa}$ & $41.2 \mathrm{Db}$ \\
\hline S.A2 & 67.Ab & $10.5 \mathrm{Ac}$ & $42.0 \mathrm{Da}$ & $68.2 \mathrm{Aa}$ & $11.5 \mathrm{Ab}$ & 41.9Da & 68.7Aa & $12.0 \mathrm{Aa}$ & $41.0 \mathrm{Da}$ \\
\hline S.A3 & 63. $\mathrm{BCb}$ & $10.8 \mathrm{Ab}$ & $44.9 \mathrm{BCa}$ & $63.5 \mathrm{Bb}$ & $10.7 \mathrm{Bb}$ & $44.2 \mathrm{Ba}$ & 65.9BCa & $12.4 \mathrm{Aa}$ & $44.5 \mathrm{Ba}$ \\
\hline \multirow[t]{2}{*}{ S.A4 } & $62.2 \mathrm{Cb}$ & $9.9 \mathrm{Bc}$ & $43.5 \mathrm{Ca}$ & $61.4 \mathrm{Cc}$ & $10.5 \mathrm{Bb}$ & $42.8 \mathrm{Cb}$ & $63.8 \mathrm{Ca}$ & $11.2 \mathrm{Ba}$ & $42.4 \mathrm{Cb}$ \\
\hline & \multicolumn{9}{|c|}{$\begin{array}{l}\text { Conv. }=\text { Conventional, } \mathrm{S} . \mathrm{A} 1=\mathrm{RS}+\mathrm{EM} 1+\mathrm{Urea} \times \mathrm{EM}-\mathrm{X}, \mathrm{S} . \mathrm{A} 2=\mathrm{RS}+\mathrm{EM} 1+\mathrm{Urea} \\
\times \mathrm{EM} 5, \mathrm{~S} . \mathrm{A} 3=\text { biochar }+ \text { compost } \times \mathrm{EM}-\mathrm{X}, \mathrm{S} . \mathrm{A} 4=\text { biochar }+ \text { compost } \times \mathrm{EM} 5, \mathrm{~B}= \\
\text { Total bacteria, } \mathrm{F}=\text { Total fungi. }\end{array}$} \\
\hline
\end{tabular}

\subsection{On sunflower growth and characters yield}

Results in table (5) illustrate that the integration between different tillage methods and soil amendment treatments had significant effects on improving sunflower yield and growth characters under the dominancy of 
the biotic stress of charcoal-rot. The observations demonstrated that under the dominancy of the severe soil borne disease; such as charcoal-rot, the integration between different agricultural practices; such as the proper tillage method and the proper soil amendment treatment; where the conventional chemical fertilization was prohibited, is a must in order to achieve an appreciated growth and yield under these conditions. The highest observations; i.e. plant height $(\mathrm{cm})$, head diameter $(\mathrm{cm})$, seed yield $(\mathrm{kg} / \mathrm{fed})$ and the oil yield $(\mathrm{kg} / \mathrm{fed})$ were obtained from the interaction treatment $\mathrm{CT} \times$ $(\mathrm{RS}+\mathrm{EM} 1+$ Urea $\times \mathrm{EM}-\mathrm{X})$, followed by CT $\times($ Biochar + compost $\times$ EM$\mathrm{X})$, respectively. While there were significant variations between the other interaction treatments. This was true in regard to all the studied characters, except for the oil yield $(\mathrm{kg} / \mathrm{fed})$, where the differences between most of the interaction treatments were insignificant, except the superior treatment; the interaction $\mathrm{CT} \times(\mathrm{RS}+\mathrm{EM} 1+\mathrm{Urea} \times \mathrm{EM}-\mathrm{X})$ and the minor treatment; the interaction of no tillage $\times$ conventional fertilization, as control.

Table (5). Effect of the interaction between different tillage methods and soil amendment treatments on sunflower growth characters and yield grown under Nubaria province conditions.

\begin{tabular}{|c|c|c|c|c|c|}
\hline \multirow[b]{2}{*}{$\begin{array}{l}\text { Tillage } \\
\text { Methods }\end{array}$} & \multirow{2}{*}{$\begin{array}{l}\text { Soil } \\
\text { amendment } \\
\text { Treatments }\end{array}$} & \multicolumn{4}{|c|}{ Studied Characters } \\
\hline & & $\begin{array}{l}\text { Plant height } \\
\text { (cm) }\end{array}$ & $\begin{array}{l}\text { Head diameter } \\
\text { (cm) }\end{array}$ & $\begin{array}{l}\text { Seed yield } \\
\text { (kg/fed) }\end{array}$ & $\begin{array}{c}\text { Oil yield } \\
\text { (kg/fed) }\end{array}$ \\
\hline \multirow{5}{*}{ No tillage } & Conv. & $127.8 \mathrm{f}$ & $9.7 \mathrm{~h}$ & 215.71 & $62.4 \mathrm{k}$ \\
\hline & S.A1 & NS & NS & NS & NS \\
\hline & S.A2 & $131.8 \mathrm{e}$ & NS & $245.7 \mathrm{j}$ & NS \\
\hline & S.A3 & NS & NS & NS & NS \\
\hline & S.A4 & NS & NS & $270.7 \mathrm{i}$ & NS \\
\hline \multirow{5}{*}{$\begin{array}{l}\text { Moderately } \\
\text { tillage }\end{array}$} & Conv. & NS & NS & $322.7 \mathrm{~h}$ & NS \\
\hline & S.A1 & NS & NS & $417.7 \mathrm{e}$ & NS \\
\hline & S.A2 & NS & NS & NS & NS \\
\hline & S.A3 & $146.9 \mathrm{c}$ & NS & $407.5 f$ & NS \\
\hline & S.A4 & NS & NS & $356.1 \mathrm{~g}$ & NS \\
\hline \multirow{5}{*}{$\begin{array}{l}\text { Conventional } \\
\text { tillage }\end{array}$} & Conv. & NS & NS & NS & NS \\
\hline & S.A1 & NS & $19.8 \mathrm{a}$ & NS & NS \\
\hline & S.A2 & NS & NS & $447.9 \mathrm{~d}$ & NS \\
\hline & S.A3 & $164.0 \mathrm{~b}$ & NS & $502.9 \mathrm{~b}$ & NS \\
\hline & S.A4 & $153.7 \mathrm{~b}$ & NS & $455.6 \mathrm{c}$ & NS \\
\hline $\begin{array}{l}\text { Conv. }= \\
\times \text { EM5 } \\
\text { Means }\end{array}$ & $\begin{array}{l}\text { Conventional, } \\
\text { S.A3= biochar }\end{array}$ & $\begin{array}{l}1=\mathrm{RS}+\mathrm{EM} 1 \\
\text { ompost } \times \mathrm{EM}\end{array}$ & $\begin{array}{l}\text { Urea } \times \text { EM-X, S.A } \\
\text { S.A4= biochar }+ \text { c }\end{array}$ & $\begin{array}{l}\mathrm{RS}+\mathrm{EM} 1+ \\
\text { post } \times \text { EM5 } \\
\text { letters }\end{array}$ & \\
\hline
\end{tabular}




\section{DISCUSSION}

The aspirational goal of a land degradation neutral world, to be realized by reducing the rate of land degradation and increasing the rate of restoration of degraded land, was agreed at the Rio +20 Conference in 2012. Land degradation was occurred through different biotic and abiotic stresses, some are natural and the others are manmade, yet soil borne diseases is one of those biotic stresses that has direct impact on loss of land cover and decrease productivity of area unit hence desertification (Grainger, 2015). He added; in order to achieve land degradation neutrality in an infested area with soil borne diseases, we should protect new lands to be infested, restore the infested lands to be productive, and engage people to let them know the most proper agriculture practice in order to achieve the land degradation neutral world by 2030 .

Tillage is one of those agricultural practices that determined to be a critical management practice to improve soil properties and to suppress soilborne diseases and decrease population density of serious soil borne pathogens such as M. phaseolina (Wrather and Kendig, 1998). This may be due to that tillage reduces populations of weeds and volunteer crop plants that harbor pathogens between crops. It also buries plant pathogens from the upper layers of the soil into deeper ones where they cause less or no disease (Dang et al., 2015).

As indicated in the results; the soil population density of $M$. phaseolina was greater in the soil with no tillage than with tillage either moderately or conventional, but with no significant difference. However, the conventional tillage method increased bacterial and fungal total counts significantly more than moderately tillage and no tillage sowing methods. Mbuthia et al. (2015) indicated that, zero tillage without residues retention resulted in very low populations of micro-flora, while conventional tillage with residue removal resulted in the predominance of total fungi, bacteria, actenomycetes and fluorescent pseudomonas. Tillage was found to enhance the propagation of the plant growth-promoting bacteria (PGPB) and other rhizosphereic beneficial microorganisms, such as biological nitrogen fixation and phosphate solubilization that can be assessed as plant growth promotion traits (Anikwe et al., 2016). In general, 60 to $90 \%$ of the total applied chemical fertilizer is lost, while only 10 to $40 \%$ remained in the soil to be taken up by plants, besides the enormous pollution that was introduced to the virgin environments through the chemical fertilization to introduce pollution as one of the most severe desertification factors to the harsh environment. In contrary, microbial inoculants have paramount significance in integrated nutrient management systems to sustain agricultural productivity and healthy environment, therefore mobilize the Millennium Sustainable Development Goals (SDG No. 15); concerning life on earth (Adesemoye and Kloepper, 2009).

Egyptian J. Desert Res., 68, No. 2, 223-242 (2018) 
Soil health is an important factor that affects plant growth promoting bacteria (PGPB) efficiency, due to several characteristics such as soil type, nutrient pool, soil moisture, microbial diversity, and soil disturbances caused by management practices; such as tillage, which all together play an important role in improving the plant growth and productivity (Anikwe et al., 2016). This can easily describe the superior results obtained by using conventional tillage then moderately tillage methods, respectively, compared to no tillage as the control treatment.

Biofertilizers, which applied as seed or soil inoculants is a terrific solution for soil fertility depletion particularly in harsh environments, where biotic or abiotic stresses prevailed and chemical fertilization seems to be a great gamble (Singh et al., 2011). It keep the soil environment rich in all kinds of micro- and macro-nutrients via nitrogen fixation, phosphate and potassium solubilization or mineralization, release of plant growth regulating substances, produce of antibiotics and biodegradation of organic matter in the soil, biocontrol of pathogens and insect pests, which operation can significantly be useful in maintaining the sustainability of various crop productions, therefore improve plant growth and productivity (Sinha et al., 2014). Similarly, Plant growth promoting rhizobacteria (PGPR) has positive impacts on plant growth and productivity; it acts as phytostimulators, biofertilizers, thus enhance crop growth and yield through nutrient uptake and plant growth regulators. It also acts as biocontrol agents by production of antibiotics, triggering induced local or systemic resistance (Bouizgarne 2013). The PGPR or co-inoculants of PGPR and arbuscular mycorrhizal fungi (AMF) can advance the nutrient use efficiency of fertilizers seven times compared to the chemical fertilizers (Adesemoye and Kloepper, 2009).

According to Tokeshi et al. (1998), beneficial microorganisms (EM) were found to be suppressive to the soil-borne plant pathogen Sclerotinia sclerotiorum. Control of fungal pathogens may be attributed to the activity of lactic acid bacteria in the beneficial microorganisms mixture that produce lactic acid, a strong sterilizing compound (Higa, 2000). As EM1 consists of lactic acid bacteria, yeasts, photosynthetic bacteria, actinomycetes and other types of organisms such as mycorrhizae, which are mutually compatible with one another and coexist in based molasses liquid culture, while EM5 exceeds with ethyl alcohol and sugar cane vinegar (Higa, 1991), so they seemed to be more applicable under the study conditions.

Soil application of organic amendments reduced the inoculum levels of $M$. phaseolina and significantly reduced the incidence of charcoal rot (Sudha and Prabhu, 2008). The addition of organic matter in soil provide disease control through variety of mechanism; such as providing antimicrobial compounds during decomposition reduced the inoculum density of the soil borne plant pathogens through changes in the general microbial balance by different mechanism (Kausar et al., 2016). Similarly, biochar, which is a carbon rich soil amendment that is produced as a 
byproduct during the pyrolysis of the agriculture wastes to produce the thermal gas, can significantly improve the gravimetric moisture content of soil, increase soil $\mathrm{pH}$ significantly. Also, biochar addition to soil alters microbial populations in the rhizosphere, albeit via mechanisms not yet understood, and may cause a shift towards beneficial microorganism populations that promote plant growth and resistance to biotic stresses. There are also some scant evidences for biochar-induced plant protection against soil borne-diseases, the induction of systemic resistance towards several plant pathogens in different crop systems (Bonanomi et al., 2015 and Jaiswal et al., 2018).

Consequently, when take into consideration all the integration of the direct and indirect impacts of tillage method (conventional, moderately and no tillage $)$ and the impacts of soil amendment treatments [(RS + EM1 + Urea $\times$ EM-X), $($ RS + EM1 + Urea $\times$ EM5), $($ biochar + compost $\times$ EM-X) and (biochar + compost $\times$ EM5)] compared to the control treatment (conventional chemical fertilization). These impacts can simply explicate the superior results obtained from the integration between conventional tillage method and RS + EM1 + Urea $\times$ EM-X, compared to the other soil amendment treatments particularly the no tillage $\times$ conventional chemical fertilization, as the control treatment.

\section{CONCLUSION}

Charcoal rot caused by M. phaseolina is a major seed and soil borne pathogen that causes root or stem rot and sometimes causes early death of maturing sunflower plants. Thus decrease the plant growth and productivity and introduce land cover loss as one of the desertification indicators to the affected areas.

Under this biotic stress, the integration between the proper agricultural practices; such as tillage methods and soil amendments where the conventional fertilization seems to be a great risk for its pollution consequences on the stressed environment, in addition to increase plant water stress as a result of damaging both the vascular and root systems.

Therefore, the integration between Conventional tillage method and $\mathrm{RS}+\mathrm{EM} 1+$ Urea $\times \mathrm{EM}-\mathrm{X}$, compared to the other tillage methods and other soil amendment treatments was the furthermost advised agricultural practices under these conditions as land degradation neutrality (LDN) practical technology that enhance land cover and area unit productivity under these conditions.

Egyptian J. Desert Res., 68, No. 2, 223-242 (2018) 


\section{REFERENCES}

A.O.A.C., Association of Official Analysis Chemists (1990). In "Official Methods of Analysis". Published by the Association of Official Analysis Chemists, $15^{\text {th }}$ ed., Washington, DC, USA.

Abdel-Ati, A.A. and A.E.A. El-Hadidy (2015). Evaluation of sunflower productivity, root-rot and damping-off control by using some agricultural practices. Egyptian J. Desert Res., 65 (2): 257-279.

Abdel-Ati, A.A. and A.E.A. El-Hadidy (2017). Integration of EM-X biofertilization and sowing methods on encouragement of sunflower productivity and charcoal rot control under reclaimed soil conditions. J. Plant Prot. Path., Mansoura Univ., 8 (4), : 155-164.

Adesemoye, A.O. and J.W. Kloepper (2009). Plant-microbes interactions in enhanced fertilizer-use efficiency. Appl. Microbiol. Biotechnol., 85: $1-12$.

Anikwe, M.A.N., J.C. Eze, M.C. Chima and E.E. Ikenganyia (2016). Soil physicochemical quality in contrasting tillage systems and itseffect on nodulation and nodulation effectivity of groundnut, Bambara groundnut and soybean in a degraded Ultisol in Agbani, Enugu Southeastern Nigeria. Rhizosphere, 1: 14-16.

Anonymous (2007). In "Sunflower (Helianthus annuus L.)". Pakistan Agric. Res. Council. Islamabad, Pakistan.

Bhattacharya, D., S. Basu, J.P. Chattapadhyay and S.K.Bose (1985). Biocontrol of Macrophomina root rot disease of jute by an antagonistic organism Aspergillus versicolor. Plant Soil, 87: 435-446.

Bonanomi, G., F. Ippolito and F. Scala (2015). A "black" future for plant pathology? Biochar as a new soil amendment for controlling plant diseases. Journal of Plant Pathology, 97: 223- 234.

Bouizgarne, B. (2013). Disease Management. In: "Bacteria for Plant Growth Promotion and Disease Management". Springer-Verlag, Berlin Heidelberg, $367 \mathrm{p}$.

Chapman, H.O. and P.E. Pratt (1978). In: "Methods of Analysis for Soils, Plants and Water". Univ. of California, Agric. Sci. Priced. Publication, 4034. 50 p.

Dang, Y.P., N.P. Seymour, S.R. Walker, M.J. Bell and D.M. Freebalm (2015). Strategic tillage in no-till farming systems in Australia's northern grains-growing regions: I. Drivers and implementations. Soil and Tillage Research,152: 104-114.

Dawood, M.G., M.S.H. Sadak and M. Hozayen (2012). Physilogical role of salicylic acid in improving performance, yield and some biochemical aspects of sunflower plant grown under newly reclaimed sandy soil. Aust. J. Basic Appl. Sci., 6 (4): 82-89.

Duncan, D.B. (1955). Multiple range and multiple F-test. Biometrics, 11: 124. 
FAO (1995). Tillage Systems in the Tropics. In: "Management Options and Sustainability Implications". FAO, Rome, Italy.

Figueiredo, M.V.B., A. Bonifacio, A.C. Rodrigues, F.F. de Araujo and N.P. Stamford (2016). In: "Beneficial Microorganisms: Current Challenge to Increase Crop Performance, Bioformulation: For Sustainable Agriculture". Springer, India, pp. 53-70.

Grainger, A. (2015). Is land degradation feasible in dry areas?. J. Arid Environ., 112: 14-24.

Higa, T. (1991). Effective microorganisms: A biotechnology for mankind. 814. Parr, J.F., S.B. Hornick, and C.E. Whitman (Eds.). Proceedings of the First International Conference on Kyusei Nature Farming. US Department of Agriculture, Washington, DC, USA.

Higa, T. (2000). An Agricultural Revolution with EM Technology. In: "Our Future Reborn". Sunmark Publishing Inc. Japan, 81 p.

Jaiswal, A.K., Y. Elad, E.R. Graber, E. Cytryn and O. Frenkel (2018). Soilborne disease suppression and plant growth promotion by biochar soil amendments and possible mode of action. Acta Horticulturae,1207: 69-76.

Kausar, H., M.R. Ismail, H.M. Saud, Z. Berahim, S.H. Habib, R. Othman and S.H. Bhuiyan (2016). Microbial Composting of Rice Straw for Improved Stability and Bioefficacy. In: "Plant, Soil and Microbes". Springerlink, p. 271-290.

Kumar, A., Y. Elad, L. Tsechansky, V. Abrol, B. Lew, R. Offenbach and R.E. Graber (2018). Biochar potential in intensive cultivation of Capsicum annuum L. (sweet pepper): crop yield and plant protection. Journal of the Science of Food and Agriculture, 98 (2): 495-503.

Mbuthia, L.W., V. Acosta-Martinez, J. De Bruyn, S. Schaeffer, D. Tyler, E. Odoi, M. Mpheshea, F. Walker and N. Eash (2015). Long term tillage, cover crop, and fertilization effects on microbial community structure, activity: implications for soil quality. Soil Biology and Biochemistry, 89: 24-34.

Morsy, S.M.A (2005). Effect of tillage system combined with NPK fertilization on damping-off and charcoal rot of sunflower. J. Agric. Env. Sci., Alex. Univ., Egypt, 4 (2): 140-163.

Purkayastha, S., B. Kaur, N. Dilbaghi, and A. Chaudthury (2006). Characterization of Macrophomina phaseolina, the charcoal rot pathogen of cluster bean, using conventional techniques and PCRRAPD based molecular markers. Plant Pathology, 55: 106-116.

Raaijmakers, J.M., T.C. Paulitz, Steinberg, C. Alabouvette and Y. Moe "nneLoccoz (2009). The rhizosphere: a playground and battlefield for soil borne pathogens and beneficial microorganisms. Plant Soil 321: 341361.

Egyptian J. Desert Res., 68, No. 2, 223-242 (2018) 
Russell, D.F. (1991). MSTAT C, Directory Crop Soil Science Dept. Michigan Univ., USA.

Sadashivaiah, A.S., K.G. Ranganathaiah and D.N. Gowda (1986). Seed health testing of Helianthus annus with special reference to Macrophomina phaseolina. Indian Phytopathol., 39: 445-447.

Seeley, H.W. and P.J. Van Demark (1981). In: "Microbes in Action". A Laboratory Manual of Microbiology. $3^{\text {rd }}$ Edition. (Freeman, W.H ed.), New York.

Singh, J.S., V.C. Pandey and D.P. Singh (2011). Efficient soil microorganisms: a new dimension for sustainable agriculture and environmental development. Agric. Ecosyst. Environ., 140: 339-353.

Sinha, R.K., D. Valani, K. Chauhan and S. Agarwal (2014). Embarking on a second green revolution for sustainable agriculture by vermiculture biotechnology using earthworms: reviving the dreams of Sir Charles Darwin. Int. J. Agric. Health Saf., 1: 50-64.

Sudha, A. and S. Prabhu (2008). Evaluation of organic soil amendments against Macrophomina phaseolina (Tassi). Journal of Biopestcides, 1 (2): 143-145.

Tokeshi, H., M.C. Alves, A.B. Sanches and D.Y. Harada (1998). Effective microorganisms for controlling the phytopathogenic fungus Sclerotinia sclerotiorum in lettuce. Parr, J.F. and S.B. Hornick (Eds.) Proceedings of $4^{\text {th }}$ International Conference on Kysei Nature Farming, Paris, France, p. 131-139, 19-21 June 1995 USA 350 pp.

Triplett, G.B., Jr., S.M. Dabney and J.H. Siefker (1996). Tillage systems for cotton on sility upland soils. Agron. J., 88: 507-512.

Verrell, G.A., S. Simpfendorfer and J.K. Moore (2017). Effect of row placement, stubble management and ground engaging tool on crown rot and grain yield in a no-till continuous wheat sequence. Soil and Tillage Research, 165: 16-22.

Wrather, J.A. and S.R. Kendig (1998). Tillage effects on Macrophomina phaseolina population density and soybean yield. Plant Disease, 82 (2): 247-250. 


\title{
تأثير إضافات التربة وطرق الحرث لمقاومة مرض العفن الفحمي لعباد

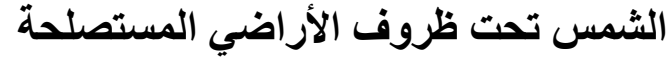

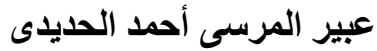 \\ قسم وقاية النبات، مركز بحد الحديرث الصحر اء، المطرية، القاهرة، مصر
}

أجريت تجربتان حقليتان في النوبارية بالظهير الصحراوي لمحافظة البحيرة بجمهورية

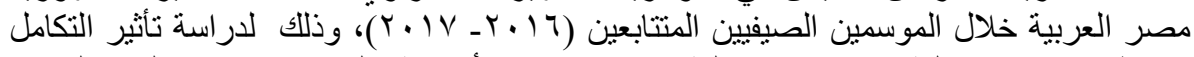

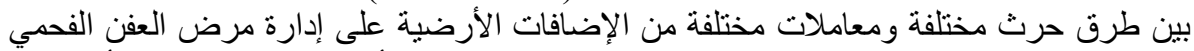

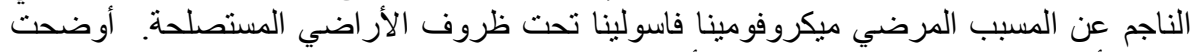

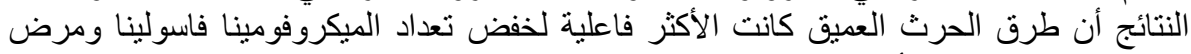

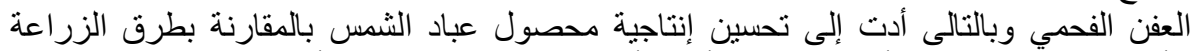

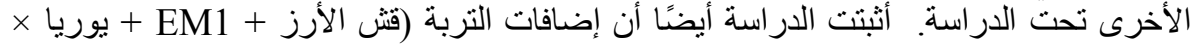

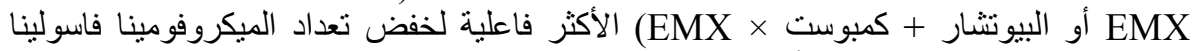

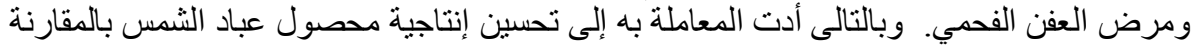

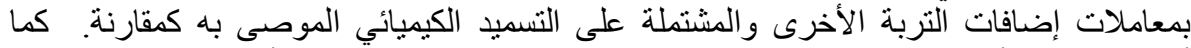

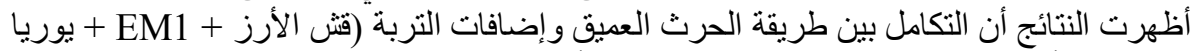

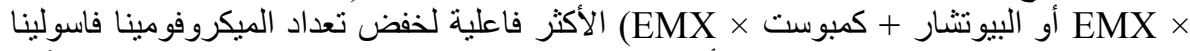

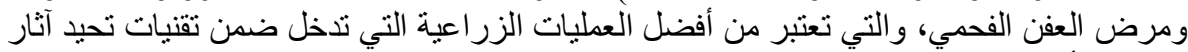

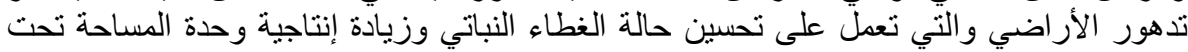

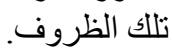

Egyptian J. Desert Res., 68, No. 2, 223-242 (2018) 